\title{
СУЧАСНИЙ СТАН ТА ПЕРСПЕКТИВИ РОЗВИТКУ ВІТЧИЗНЯНОГО ПЛЕМІННОГО СВИНАРСТВА
}

\author{
Гетя Андрій Анатолійович \\ доктор сільськогосподарських наук, профессор \\ Національний університет біоресурсів і природокористування України \\ ORCID: 0000-0002-4747-9261 \\ E-mail: getya@ukr.net \\ Супрун Ірина Олександрівна \\ кандидат сільськогосподарських наук, доцент \\ Національний університет біоресурсів і природокористування України \\ ORCID: 0000-0001-8105-1923 \\ E-mail: isuprun@nubip.edu.ua
}

\begin{abstract}
Розвиток свинарства є однією з перспективних і стратегічних галузей нашої країни. Проте незважаючи на затребуваність продукції свинарства вітчизняним покупцем, ринок даної продукції є нестабільним і постійно потребує державної підтримки. Окремим складним питанням є позбавлення або присвоєння статусу суб'єкта племінної справи у свинарстві. Відповідно до вітчизняного законодавства в тваринництві атестація суб'єктів племінної справи здійснюється щорічно, але останнім часом кількість бажаючих отримати статус племінного господарства зменшується. Основною причиною є відсутність попиту на племінну продукцію та збитковість ї̈ виробництва. Відтак цілий ряд селекціонерів вважає актуальним постійний моніторинг стану племінних ресурсів галузі свинарства. Тому метою наших досліджень був аналіз та висвітлення сучасного стану племінного свинарства в Україні, характеристика вітчизняних порід свиней, якіє базою для племінної роботи в Україні та прогнозування їх значення у породотворчому процесі. Для аналізу стану розвитку свинарства в Україні був використаний Державний реєстр суб'єктів племінної справи у тваринництві за 2005-2020 рр. Проведено аналіз стану розвитку племінного свинарства в Україні. Показано, що в умовах тривалої кризи за останні 15 років племінне свинарство в Україні зазнало суттєвого скорочення чисельності поголів'я, звуження породної структури та зміни форми власності. 32005 до 2012 року поголів'я племінних свиней залишалося відносно стабільним. У 2014 році частина племінного поголів'я залишилась на непідконтрольній території Донецької та Луганської областей та Криму, тому офіційна статистика поголів'я племінних свиней в Україні за рік скоротилося на 72,6 тис. голів. Протягом періоду 2014-2017 рр чисельність племінного поголів'я стабілізувалась на рівні 350-340 тис. голів, але з 2018 року спостерігається стрімке його скорочення. Припинили існування за останні два роки племінні господарства на заході України в Закарпатській області, на півночі - в Житомирській та Рівненській областях. В центральному регіоні України племінне свинарство найбільше розвинуте у Полтавській області і налічує 19,8 тис. голів. Таким чином, станом на початок 2020 рок племінне поголів'я свиней в Україні порівняно з 2012-2010 роками скоротилося на 70\%-77\%. Лідерами за чисельністю племінних свиней є Тернопільська, Запорізька, Дніпропетровська, Полтавська, Львівська області. На даний час племінна база свинарства в Україні складається з 72 господарств, де зареєстровано 151,726 тис. голів племінних свиней 10 порід: великої білої, дюрок, ландрас, п'єтрен, полтавської м'ясної, уельської, української м'ясної, української степової білої, української степової рябої, червоної білопоясої. Найчисельнішими за кількістю племінного поголів'я породами впродовж останніх15 років залишаються велика біла та ландрас.
\end{abstract}

Ключові слова: свинарство, порода, поголів'я, кнури-плідники, свиноматки.

DOI: https://doi.org/10.32845/bsnau.lvst.2021.2.22

Розвиток свинарства є і буде однією з перспективних і стратегічних галузей нашої країни. Незважаючи на те, що саме продукція свинарства найбільш затребувана вітчизняним покупцем, ринок даної продукції $є$ нестабільним і постійно потребує державної підтримки. Історично так склалося, що галузь свинарства України базується на використанні тварин імпортного та вітчизняного походження як м'ясного, так і сального напрямків продуктивності. Продукцію виробляють в умовах великих промислових підприємств та господарств населення різних рівнів годівлі. Але при цьому простежується тенденція до зміни породного складу галузі, інтенсивного використання гібридизації, нерівномірного розміщення свинарських господарств по регіонах країни, скорочення поголів'я на тлі незначного підвищення продуктивності тварин. Окремі аналітичні дослідження показують, що у 2016 році, порівняно з 1991, поголів'я свиней у всіх категоріях підприємств, включаючи господарства населення, скоротилося в 2,9 рази, а виробництво свинини - в 2,3 рази. Із

загального поголів'я 6688,9 тисяч свиней, лише $53,4 \%$ утримувалося на сільськогосподарських підприємствах, а решта - в господарствах населення. У вітчизняному свинарстві спостерігається незбалансованість попиту і пропозиції, часом зниження якості продукції. Окремим складним питанням $€$ позбавлення або присвоєння статусу суб'єкта племінної справи у свинарстві, яке відповідно до вітчизняного законодавства в тваринництві, здійснюється щорічно, але кількість господарств бажаючих отримати такий статус неухильно зменшується. Основною причиною $є$ відсутність попиту на племінну продукцію та збитковість її виробництва.

Відтак цілий ряд селекціонерів (Гетя, А.А., 2009 [5], Волощук, В.М., 2014 [4], Повод, М.Г., 2017 [17], Бащенко, M.І., [18], 2017, Войтенко С.Л., 2018 [2, 3]) вважає актуальним постійний моніторинг стану племінних ресурсів галузі свинарства 3 метою корегування напряму селекції, підвищення генетичного потенціалу тварин у межах породи, збереження генетичного біорізноманіття виду.

Вісник Сумського національного аграрного університету 
Тому метою наших досліджень було провести аналіз сучасного стану племінного свинарства в Україні з урахуванням зазначених масштабних змін, а також висвітлити характеристику наявних порід свиней, які $є$ базою для племінної роботи.

Матеріали та методи досліджень. Для аналізу стану розвитку свинарства в Україні були використані статистичні збірники про стан тваринництва в Україні [6], а також Державні реєстри суб'єктів племінної справи у тваринництві за 2005-2020 pp. [7-16]. Для дослідження використано методи системного узагальнення, графічний, аналітичний та порівняльно-статистичний.

Результати досліджень. Станом на 01.012020 року в Україні налічується 72 племінних господарства де розводять 151,726 тис. голів племінних свиней, в тому числі 566 кнурів-плідників та 16079 свиноматок. Чисельність поголів'я племінних свиней в Україні в різних областях та природнокліматичних зонах суттєво відрізняється (рис. 1). Традиційно значна кількість племінного поголів'я зосереджена в центра- льних (Полтавська), східних (Дніпропетровська, Запорізька та західних областях (Тернопільська, Львівська). В цілому, розміщення поголів'я співпадає з розташуванням природнокліматичних зон в Україні: найбільше тварин у центральній зоні з поступовим їх зменшенням в напрямку до півдня ( племінне поголів'я у Донецькій та Луганській областях враховано лише з частини підконтрольної території). Беззаперечним лідером з племінного свинарства в Україні $€$ Тернопільска область на території якої знаходиться 22107 голів, або понад 14,5 \% всього поголів'я.

Необхідно відмітити, що племінним поголів'ям, за законодавством України, вважається таке, яке розміщено на зареєстрованих сільськогосподарських підприємствах, а не у домогосподарствах. Враховуюче факт скорочення поголів'я свиней у сільськогосподарських підприємствах, стає зрозумілим і зменшення племінного поголів'я в них. Так, у 1991 році свиней налічувалося близько 19,5 млн голів. Протягом наступних десяти років чисельність скоротилася до 7,6 млн голів.

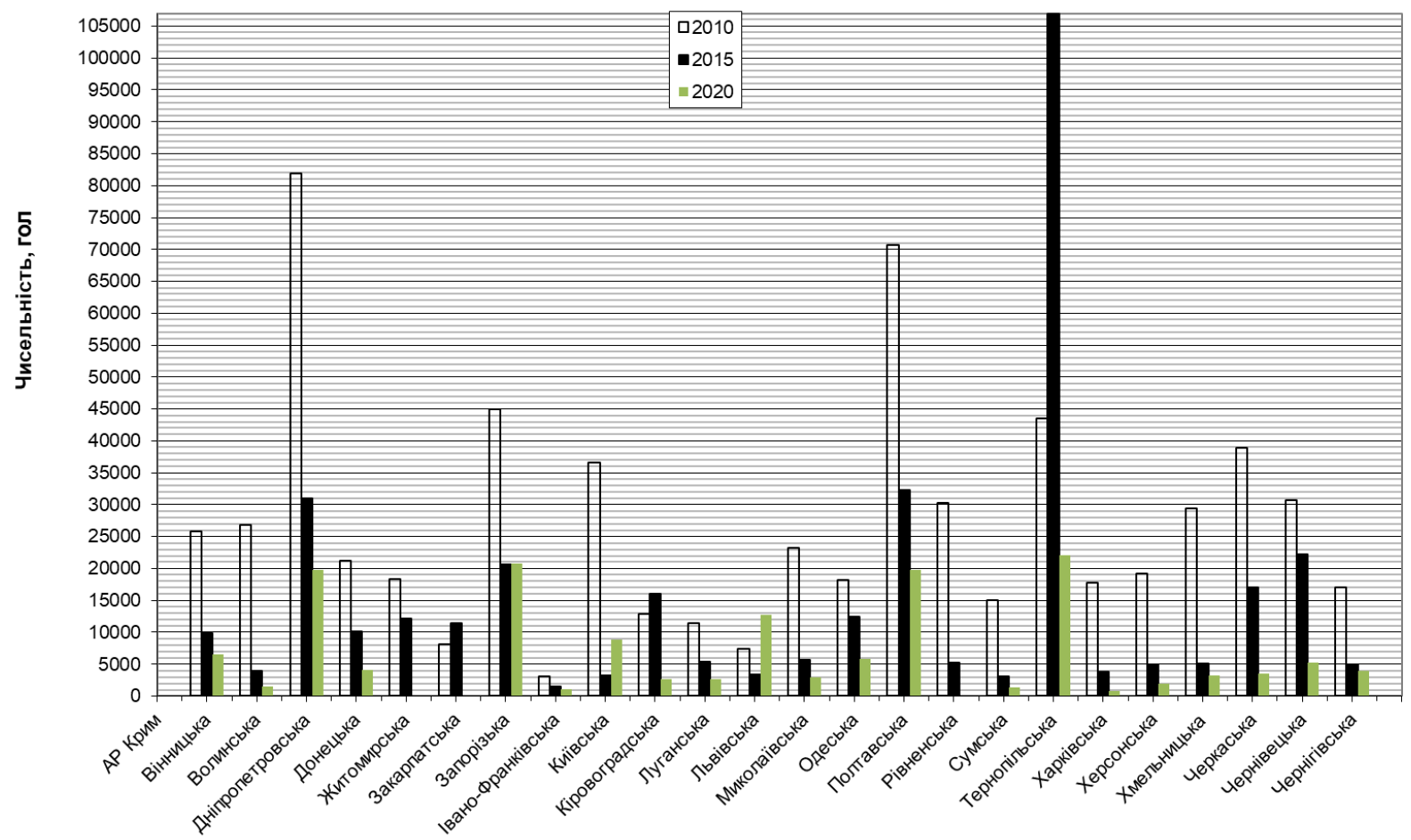

Рис. 1. Розподіл чисельності поголів'я племінних свиней по областях України упродовж 2010-2020 pp.

Основою для подальшого розвитку свинарства в нашій країні $є$ генетичні ресурси та племінна база. В цілому ситуація з поголів'ям племінних свиней відображає розвиток свинарства в Україні (рис. 2).

З 2005 до 2012 року поголів'я племінних свиней залишалося відносно стабільним і на початок 2012 року становило 505,5 тис голів. У 2014 році частина племінного поголів'я залишилась на непідконтрольній території Донецької та Луганської областей та Криму, тому офіційна статистика поголів'я племінних свиней в Україні за рік скоротилося на 72,6 тис. голів. Упродовж періоду 2014-2017 рр. чисельність племінного поголів'я стабілізувалась на рівні 350-340 тис. голів, але з 2018 року спостерігається стрімке його скорочення. Така динаміка пояснюється у тому числі й ско- роченням підприємств 3 низьким рівнем ветеринарного захисту. Таким чином, станом на початок 2020 року племінне поголів'я свиней в Україні скоротилося на 353,8 тис голів (70\%) порівняно з 2012 роком і на $77 \%$ порівняно з максимальним розвитком у 2010 році.

За останні два роки припинили існування племінні господарства на заході України в Закарпатській області, на Півночі - в Житомирській та Рівненській областях. В центральному регіоні України племінне свинарство найбільше розвинуте у Полтавській області і налічує 19,8 тис. голів.

На сході України найбільше свиней залишилося у Дніпропетровській та Запорізькій областях. Нажаль, в цьому регіоні за останні 8 років реорганізувались чи залишились на 
непідконтрольній території племінні господарства в Донецькій, Луганській областях. Загалом в Донецькій області за проаналізований період поголів'я племінних свиней скоротилось у п'ять разів.

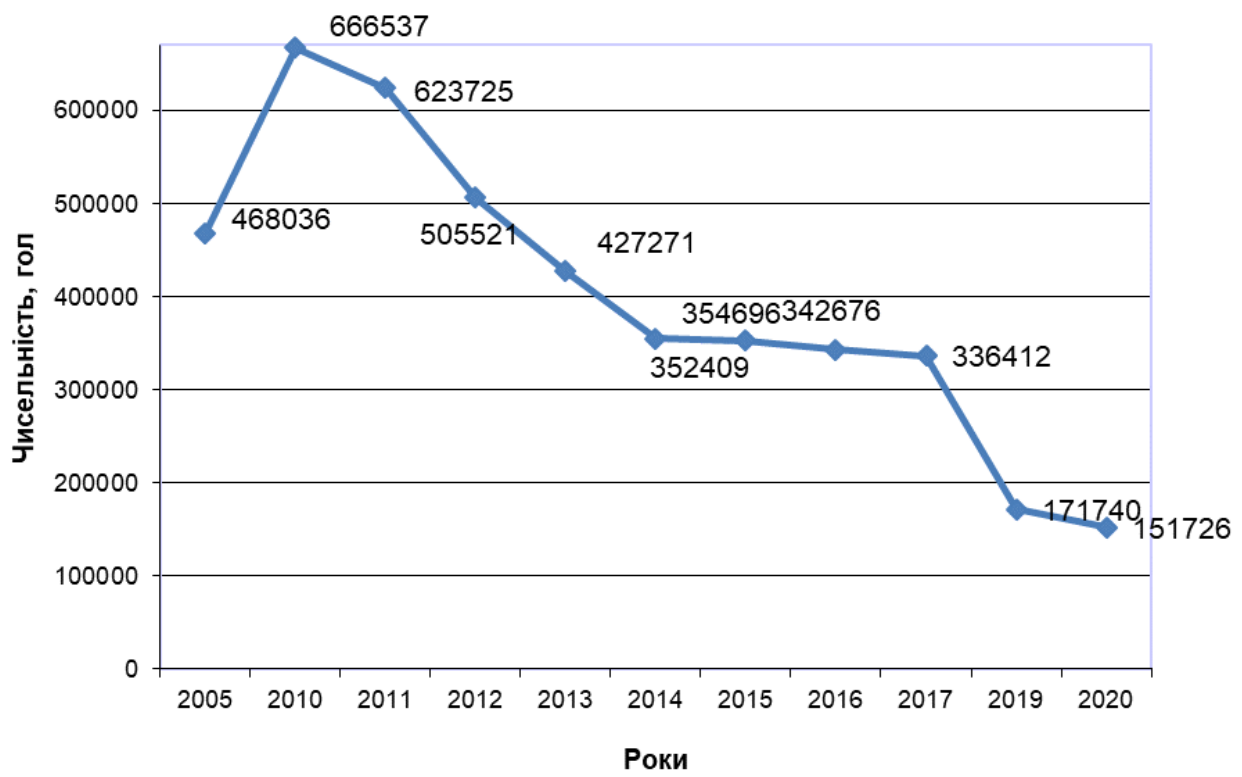

Рис. 2. Динаміка чисельності племінних свиней в Україні за період 2005-2020 рр. [7-16]

В цілому ситуація з племінним свинарством, як і $з$ усім племінним тваринництвом $€$ складною. Оскільки, державна система організації племінної роботи по суті застаріла. Фактично державою визнаються племінними лише тварини, розміщені в атестованих господарствах, які в свою чергу повинні бути занесені в відповідний державний реєстр. Ці господарства повинні відповідати мінімальним критеріям за поголів'ям та продуктивністю поголів'я залежно від породи. Процедура підтвердження всіх вимог є достатньо складною для господарств, тому вони не бажають її проходити. Так як у державі відсутні будь-які інструменти стимулювання галузі свинарства, затрати на участь в державній схемі організації селекційної роботи не компенсуються жодним чином. В таких умовах підприємства, які не мають племінного статусу можуть займатись селекційною роботою в межах свого господарства не інформуючи державу і не координуючи свою роботу з державними органами та іншими господарствами. Фактично племінна цінність поголів'я у товарних підприємствах може бути вищою, ніж в племінних, що дискредитує всю систему.

Достатньо складною є і процедура реєстрації нових популярних порід в Україні. Господарства імпортують тварин нових порід, які їм цікаві, однак не реєструють їх у племінному реєстрі. Таким чином, офіційний перелік порід в Україні виглядає дещо архаїчно і не відповідає дійсності. Фактично державний реєстр і державна система племінної роботи живе своїм життям, а господарства з розведення свиней своїм.

Щодо офріційної породної структури племінного поголів'я, то на сьогодні в Україні розводять свиней 10-ти порід: великої білої, дюрок, ландрас, п'єтрен, полтавської м'ясної, уельської, української м'ясної, української степової білої, української степової рябої, червоної білопоясої (табл. 1). Більшість племінного поголів'я відноситься до порід універсального та беконного напрямків продуктивності.

Чисельність та питома вага поголів'я племінних свиней

Таблиця 1 різних порід по Україні за період 2005-2020 рр.

\begin{tabular}{|l|l|c|c|c|c|c|c|c|c|}
\hline \multirow{2}{*}{ № ппрода } & \multicolumn{2}{|c|}{ Пп } & \multicolumn{2}{|c|}{2005} & \multicolumn{2}{|c|}{2010} & \multicolumn{2}{|c|}{2015} & \multicolumn{2}{c|}{2020} \\
\cline { 3 - 10 } & & Голів & Частка, $\%$ & Голів & Частка, $\%$ & Голів & Частка, $\%$ & Голів & Частка, $\%$ \\
\hline 1. & Велика біла & 396055 & 84,62 & 463004 & 69,46 & 166100 & 47,13 & 88307 & 58,07 \\
\hline 2. & Велика чорна & 5471 & 1,17 & 2305 & 0,34 & 583 & 0,16 & - & - \\
\hline 3. & Дюрок & 3966 & 0,84 & 4871 & 0,73 & 5543 & 1,57 & 4541 & 2,99 \\
\hline 4. & Ландрас & 21578 & 4,61 & 136801 & 20,52 & 155096 & 44,01 & 60163 & 32,05 \\
\hline 5. & Миргородська & 2483 & 0,53 & 6280 & 0,94 & 2523 & 0,72 & - & - \\
\hline 6. & П'єтрен & - & - & 545 & 0,08 & 2132 & 0,60 & 2480 & 1,63 \\
\hline 7. & Полтавська м'ясна & 9288 & 1,98 & 16962 & 2,54 & 9116 & 2,59 & 5005 & 3,30 \\
\hline 8. & Уельська & 502 & 0,10 & 322 & 0,05 & 1470 & 0,41 & 855 & 0,56 \\
\hline 9. & Українська м'ясна & 18795 & 4,02 & 20902 & 3,14 & 6548 & 1,85 & 401 & 0,26 \\
\hline 10. & Українська степова біла & 5773 & 1,23 & 4023 & 0,60 & 737 & 0,20 & 596 & 0,39 \\
\hline 11. & Українська степова ряба & 330 & 0,07 & 107 & 0,01 & 120 & 0,03 & 84 & 0,05 \\
\hline 12. & Червона білопояса & 3373 & 0,72 & 10415 & 1,56 & 5647 & 1,60 & 1029 & 0,67 \\
\hline & Разом & 468036 & 100 & 666537 & 100 & 352409 & 100 & 151726 & 100 \\
\hline
\end{tabular}


Галузь свинарства як і тваринництво в цілому підкорена настроям споживачів. Зміна уподобань населення та очевидне зміщення акцентів від енергоємних, а тому жировмісних продуктів до більш пісних вперше була відмічена в Європі починаючи з 60-х років. На той час припадає період економічного зростання і з цим пов'язана зміна харчових пріоритетів населення Європи, адже споживання висококалорійних продуктів вже не було питанням його виживання, а обсяги фізичної праці значно скоротилися. 3 того часу спостерігається тенденція до споживання низькокалорійних продуктів та зменшення жиру в продуктах харчування. Такі зміни не могли не зачепити тваринництво, зокрема свинарство, наслідком чого стала поява терміну «м'ясне свинарство» і затребуваність м'ясних та беконних порід свиней. Зміну настроїв споживачів в Україні помітно в динаміці за 10 останніх років (рис. 3-4).

Свинарство України, як і більшості країн, зосереджу-

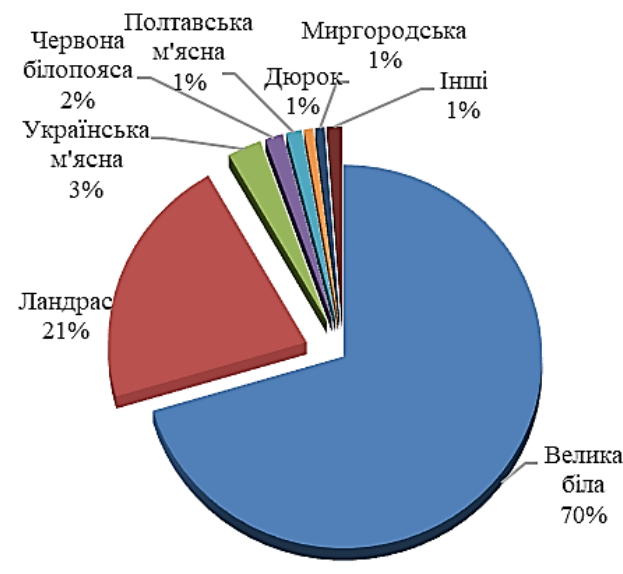

\section{Рис. 3. Питома вага племінних свиней різних порід в Україні станом на 1.01. 2010 року [8]}

До нечисленних локальних порід відносяться українська степова біла і українська степова ряба, уельска які розводяться в одному або двох господарствах з поголів'ям не більше 200 кнурів і маток. Але якщо уельську породу чи п'єтрен можна, відродити в Україні за необхідності, шляхом завезення представників даного генотипу з інших країн, то зберігати вітчизняні українську степову білу, українську степову рябу породи є нашим обов'язком. Якщо не вжити належних заходів, то доля миргородської породи чекає й інші малочисельні вітчизняні породи: полтавську м'ясну, яку розводять у 4 господарствах; українську м'ясну, яка залишилась лише у 2 племінних господарствах; червону білопоясу та вже згадувані українську степову білу, українську степову рябу породи (див. табл. 1).

Висновки. 1 Очевидно, що Україна має природнокліматичні та споживчі передумови для розвитку галузі свинарства. Крім внутрішнього ринку необхідно шукати можливості для виходу на зовнішні ринки.

2. Племінна справа у свинарстві в Україні не відповідає сучасним вимогам. Загальна кількість племінного поголів'я в 151,7 тис голів $€$ явно недостатньою для потреб виробництва. Особливо критичною ситуація є для таких порід, як полтавська м'ясна, українська м'ясна, червона білопояса. ється на розведенні двох-трьох порід - великої білої, ландрас і окремих порід м'ясного напрямку продуктивності, а інші поступово витісняються з ринку, про що свідчить чисельність їх поголів'я. Аналіз бази даних свідчить, що провідна позиція за кількістю племінного поголів'я в породі належить великій білій породі - 58,07\% від загальної кількості основних кнурів і свиноматок в племінних господарствах і породі ландрас - 32,05 \%. Інші породи залишаються малочисельними (див. табл. 1).

Згідно з нашим аналізом, частка великої білої породи універсального напрямку продуктивності помітно зменшилась поступившись породі беконного напрямку ландрас. У 2020 році серед племінного поголів'я нажаль не зареєстровано вітчизняної миргородської породи сального напрямку продуктивності, яка ще у 2010 році розводилась у 5 господарствах і налічувала 6280 голів.

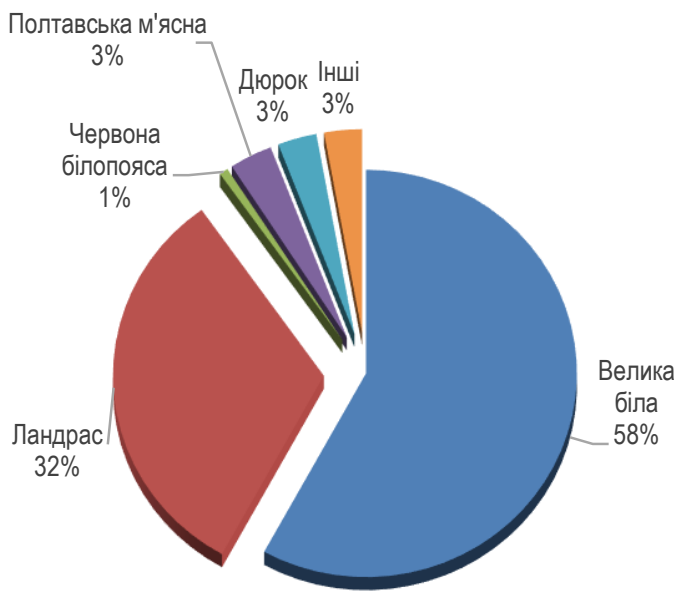

\section{Рис. 4. Питома вага племінних свиней різних порід в Україні станом на 1.01. 2020 року [16 ]}

Критично скоротилось кількість господарств, які замаються племінною справою у свинарстві.

3. В Україні не здійснюється селекція багатьох популярних порід свиней, які користуються попитом у виробників і вже $€$ наявними в країні.

4. Миргородська та українська степова ряба породи належать до вітчизняних порід, однак через відсутність організованої селекційної роботи вони можуть бути втраченими.

5. Для поліпшення стану свинарства в Україні необхідно виконати комплекс заходів, зокрема

- поширити систему державної підтримки на господарства з розведення свиней;

- допомагати в пошуку ринків збуту для племінних тварин за кордоном;

- задіяти механізми державної підтримки для оптимізації племінної бази;

- визнавати реєстри племінних тварин, які ведуться об'єднаннями виробників та асоціаціями;

- спростити процедуру реєстрації виробничих потужностей для виробництва локальних сирів.

Реалізація зазначених кроків сприятиме розвитку свинарства в Україні та слугуватиме основою для виробниц- 
тва достатньої кількості високоякісних продуктів харчування та збереження традиційних харчових уподобань різних

регіонів країни.

\section{Список використаної літератури:}

1. Вдовенко, Н.М. Регулювання ринку свинини України в умовах євроінтеграції: [монографрія] / Н. М. Вдовенко, Н. П. Грищенко, В. С. Шепелєв. - К: Кондор-Видавництво, 2017. - 371 с.

2. Войтенко С.Л. Стан та тенденції розвитку свинарства на племінній основі / С. Л. Войтенко // Науковий вісник "Асканія-Нова". - $\quad 2018 . \quad$ - $\quad$ Вип. $11 . \quad$ - $\quad$ C. $157-169 . \mid \quad$ http://www.irbis-nbuv.gov.ua/cgibin/irbis_nbuv/cgiirbis 64.exe?!21DBN=LINK\&P21DBN=UJRN\&Z21ID=\&S21REF=10\&S21CNR=20\&S21STN=1\&S21FMT=ASP $\mathrm{m}$ eta\&C21COM=S\&2_S21P03=FILA=\&2_S21STR=nvan_2018_11_19

3. Войтенко, С.; Вишневский, Л.; Петренко, С. Свиноводство Украины: этапы развития, продуктивность животных и качество продукции. In: Zootehnie şi Biotehnologii agricole materialele Simpozionului Ştiinţific Internaţional „85 ani ai Facultăţii de Agronomie - realizări şi perspective", dedicat aniversării a 85 de ani de la fondarea Universităţii Agrare de Stat din Moldova . Vol. 52(2), 25 septembrie 2018, Chișinău. Chişinău, Republica Moldova: Universitatea Agrară de Stat din Moldova, 2018, pp. 126-132. https://ibn.idsi.md/ro/vizualizare articol/96094

4. Волощук, В.М. Стан і перспективи розвитку галузі свинарства / В. М. Волощук // Вісник аграрної науки. - 2014. - № 2. - C. $17-20$.

5. Гетя А. А. Організація селекційного процесу в сучасному свинарстві: Монографія / Гетя А. А. - Полтава: Полтавський літератор, 2009. - 192 с

6. Державна служба статистики України. - [Електронний ресурс] - Режим доступу: www.ukrstat.gov.ua

7. Державний племінний реєстр 2005 рік. Державний науково-виробничий концерн «Селекція», 2006. Т. II. 310с.

8. Державний племінний реєстр за 2010 рік. Київ: Укрплемоб'єднання, 2011. Т. ІІ. 332с.

9. Державний реєстр суб'єктів племінної справи у тваринництві за 2012 рік / за ред. С. В. Прийми. Київ, 2013. Т. ІІ. 319 c. derjplemreestr_tom2_2014.pdf (animalbreedingcenter.org.ua)

10. Державний реєстр суб'єктів племінної справи у тваринництві за 2013 рік / за ред. С. В. Прийми. Київ, 2014. Т. ІІ. 319 c. deriplemreestr_tom2_2014.pdf (animalbreedingcenter.org.ua) 1

11. Державний реєстр суб'єктів племінної справи у тваринництві за 2014 рік / за ред. С. В. Прийми. Київ, 2015. Т. ІІ. 319 c. derjplemreestr_tom2_2014.pdf (animalbreedingcenter.org.ua) 1

12. Державний реєстр суб'єктів племінної справи у тваринництві за 2015 рік / за ред. С. В. Прийми. Київ, 2016. Т. ІІ. 319 c. deriplemreestr tom2_2015.pdf (animalbreedingcenter.org.ua)

13. Державний реєстр суб'єктів племінної справи у тваринництві за 2016 рік / за ред. С. В. Прийми. Київ, 2017. Т. II. 307

file://animalbreedingcenter.org.ua/derjplemreestr\%20\%5b\%D0\%94\%D0\%B0\%D1\%82\%D0\%B0\%20\%D0\%B7\%D0\%B2\%D0\%B5\% D1\%80\%D0\%B5\%D0\%BD\%D0\%B5\%D0\%BD\%D0\%BD\%D1\%8F\%20

307

14. Державний реєстр суб'єктів племінної справи у тваринництві за 2017 рік /за ред. С. В. Прийми. Київ, 2018. Т. II.

file://animalbreedingcenter.org.ua/deriplemreestr $\% 20 \% 5 \mathrm{~b} \% \mathrm{D} 0 \% 94 \% \mathrm{D} 0 \% \mathrm{~B} 0 \% \mathrm{D} 1 \% 82 \% \mathrm{D} 0 \% \mathrm{~B} 0 \% 20 \% \mathrm{D} 0 \% \mathrm{~B} 7 \% \mathrm{D} 0 \% \mathrm{~B} 2 \% \mathrm{D} 0 \% \mathrm{~B} 5 \%$ $\mathrm{D} 1 \% 80 \% \mathrm{D} 0 \% \mathrm{~B} 5 \% \mathrm{D} 0 \% \mathrm{BD} \% \mathrm{D} 0 \% \mathrm{~B} 5 \% \mathrm{D} 0 \% \mathrm{BD} \% \mathrm{D} 0 \% \mathrm{BD} \% \mathrm{D} 1 \% 8 \mathrm{~F} \% 20$

15. Державний реєстр суб'єктів племінної справи у тваринництві за 2018 рік / за ред. С.В. Прийми. Київ, 2019. Т. II. 294

file://animalbreedingcenter.org.ua/derjplemreestr\%20\%5b\%D0\%94\%D0\%B0\%D1\%82\%D0\%B0\%20\%D0\%B7\%D0\%B2\%D0\%B5\% D1\%80\%D0\%B5\%D0\%BD\%D0\%B5\%D0\%BD\%D0\%BD\%D1\%8F\%20

16. Державний реєстр суб'єктів племінної справи у тваринництві за 2019 рік / за ред. С.В. Прийми. Київ, 2020. Т. II. 294 c. deriplemreestr_tom2_2019.pdf (animalbreedingcenter.org.ua)

17. Повод М.Г. Відтворювальна здатність звиноматок зарубіжної селекції в умовах інтенсивної технології / М. Г. Повод, О. М. Храмова // Вісник Сумського національного аграрного університету. Серія: Тваринництво. - Суми, 2017. - № 5(2). - С. 119 - 122.

18. Тваринництво України: стан, проблеми, шляхи розвитку (1991 -2017-2030 рр); за ред. акад. НААН М. І. Бащенка. Київ : Аграрна наука, 2017.160 с.

\section{References:}

1. Derzhavna sluzhba statystyky Ukrainy [State Statistics Service of Ukraine]. Available at : http://www.ukrstat.gov.ua

2. Hetia A.A. Orhanizatsiia selektsiinoho protsesu v suchasnomu svynarstvi: Monohrafiia [Organization of the selection process in modern pig breeding:]/ Hetia A A. - Poltava: Poltavskyi literator, 2009. - $192 p$

3. Povod, M.H., Khramova, O.M. (2017). Vidtvoriuvalna zdatnist svynomatok zarubizhnoi selektsii v umovakh intensyvnoi tekhnolohii [Reproductive ability of sows of foreign breeding in conditions of intensive technology]. Visnyk Sumskoho natsionalnoho ahrarnoho universytetu. Seriia: Tvarynnytstvo, 5(2), P119 - 122.

4. Pryjma, S. V. ed., 2013. Derzhavnyj reyestr subyektiv pleminnoyi spravy u tvarynnycztvi za 2012 rik [State register of subjects of breeding business in animal husbandry for 2012]. Kyiv: Ukraine.deriplemreestr tom2_2012.pdf (animalbreedingcenter.org.ua)

5. Pryjma, S. V. ed., 2014. Derzhavnyj reyestr subyektiv pleminnoyi spravy u tvarynnycztvi za 2013 rik [State register of 
subjects of breeding business in animal husbandry for 2013]. Kyiv: Ukraine.deriplemreestr tom2 2013.pdf (animalbreedingcenter.org.ua)

6. Pryjma, S. V. ed., 2015. Derzhavnyj reyestr subyektiv pleminnoyi spravy u tvarynnycztvi za 2014 rik [State register of subjects of breeding business in animal husbandry for 2014]. Kyiv: Ukraine.

7. Pryjma, S. V. ed., 2016. Derzhavnyj reyestr subyektiv pleminnoyi spravy u tvarynnycztvi za 2015 rik [State register of subjects of breeding business in animal husbandry for 2015]. Kyiv: Ukraine.file://animalbreedingcenter.org.ua/deriplemreestr\%20\%5b\%D0\%94\%D0\%B0\%D1\%82\%D0\%B0\%20\%D0\%B7\%D0\%B2\%D 0\%B5\%D1\%80\%D0\%B5\%D0\%BD\%D0\%B5\%D0\%BD\%D0\%BD\%D1\%8F\%20

8. Pryjma, S. V. ed., 2017. Derzhavnyj reyestr subyektiv pleminnoyi spravy u tvarynnycztvi za 2016 rik [State register of subjects of breeding business in animal husbandry for 2016]. Kyiv: Ukraine.file://animalbreedingcenter.org.ua/deriplemreestr\%20\%5b\%D0\%94\%D0\%B0\%D1\%82\%D0\%B0\%20\%D0\%B7\%D0\%B2\%D 0\%B5\%D1\%80\%D0\%B5\%D0\%BD\%D0\%B5\%D0\%BD\%D0\%BD\%D1\%8F\%20

9. Pryjma, S. V. ed., 2018. Derzhavnyj reyestr subyektiv pleminnoyi spravy u tvarynnycztvi za 2017 rik [State register of subjects of breeding business in animal husbandry for 2017]. Kyiv: Ukraine.file://animalbreedingcenter.org.ua/deriplemreestr\%20\%5b\%D0\%94\%D0\%B0\%D1\%82\%D0\%B0\%20\%D0\%B7\%D0\%B2\%D 0\%B5\%D1\%80\%D0\%B5\%D0\%BD\%D0\%B5\%D0\%BD\%D0\%BD\%D1\%8F\%20

10. Pryjma, S. V. ed., 2019. Derzhavnyj reyestr subyektiv pleminnoyi spravy u tvarynnycztvi za 2018 rik [State register of subjects of breeding business in animal husbandry for 2018]. Kyiv: Ukraine.file://animalbreedingcenter.org.ua/deriplemreestr\%20\%5b\%D0\%94\%D0\%B0\%D1\%82\%D0\%B0\%20\%D0\%B7\%D0\%B2\%D 0\%B5\%D1\%80\%D0\%B5\%D0\%BD\%D0\%B5\%D0\%BD\%D0\%BD\%D1\%8F\%20

11. Pryjma, S. V. ed., 2020. Derzhavnyj reyestr subyektiv pleminnoyi spravy u tvarynnycztvi za 2019 rik [State register of subjects of breeding business in animal husbandry for 2019]. Kyiv: Ukraine.deriplemreestr tom2_2019.pdf (animalbreedingcenter.org.ua) Selekciya.

12. State Tribal Register 2005, 2006. Kyiv: Ministry of Agrarian Policy of Ukraine. State Scientific and Production Concern

13. State Tribal Register 2010, 2011. Kyiv: Ministry of Agrarian Policy of Ukraine. Ukrplemobyednannya.

14. Tvarynnytstvo Ukrainy: stan, problemy, shliakhy rozvytku (1991 -2017-2030 rr)[ Livestock of Ukraine: state, problems, ways of development]; za red. akad. NAAN M. I. Bashchenka. Kyiv : Ahrarna nauka, 2017.160 p.

15. Vdovenko, N. M., Hryshchenko, N. P., Shepeliev, V. S (2017). Rehuliuvannia rynku svynyny Ukrainy v umovakh yevrointehratsii [Regulation of the pork market of Ukraine in the conditions of European integration]. Kyiv: KondorVydavnytstvo, $371 \mathrm{p}$.

16. Voloshchuk V. M. (2014). Stan i perspektyvy rozvytku haluzi svynarstva [Status and prospects of the pig industry]. Visnyk ahrarnoi nauky, 2, $17-20$.

17. Voitenko S.L. Stan ta tendentsii rozvytku svynarstva na pleminnii osnovi / S. L. Voitenko // Naukovyi visnyk "Askaniia-Nova". $\quad$ - $\quad 2018 . \quad$ - $\quad$ Vyp. $\quad 11 . \quad$ - $\quad$ S. $\quad 157-169 . \mid \quad$ http://www.irbis-nbuv.gov.ua/cgibin/irbis nbuv/cgiirbis 64.exe?|21DBN=LINK\&P21DBN=UJRN\&Z21ID=\&S21REF=10\&S21CNR=20\&S21STN=1\&S21FMT=ASP $\mathrm{m}$ eta\&C21COM=S\&2_S21P03=FILA=\&2_S21STR=nvan_2018_11_19

18. Voitenko, S.; Vyshnevskyi, L.; Petrenko, S. Svynovodstvo Ukrayny: эtapy razvytyia, produktyvnost zhyvotnykh y kachestvo produktsyy. In: Zootehnie şi Biotehnologii agricole materialele Simpozionului Ştiinţific Internaţional „,5 ani ai Facultăţi de Agronomie - realizări şi perspective", dedicat aniversării a 85 de ani de la fondarea Universităţii Agrare de Stat din Moldova . Vol. 52(2), 25 septembrie 2018, Chișinău. Chişinău, Republica Moldova: Universitatea Agrară de Stat din Moldova, 2018, pp. 126-132. https://ibn.idsi.md/ro/vizualizare_articol/96094

Suprun Iryna Oleksandrivna, PhD, Associate Professor

Getya Andriy Anatoliiovych, Doctor of Agricultural Sciences, Professor

National University of life and environmental sciences of Ukraine (Kyiv, Ukraine)

Current state and prospects of development of tribal resources of pigs in Ukraine

The development of pig breeding is one of the promising and strategic industries of our country. However, despite the demand for pig products by domestic buyers, the market for these products is unstable and constantly needs government support. $A$ separate difficult issue is the deprivation or assignment of the status of a subject of tribal breeding. The main reason is the lack of demand for breeding products and unprofitable production. Therefore, the aim of our research was to analyze and highlight the current state of breeding tribal pigs in Ukraine, the characteristics of domestic breeds of pigs, which could be basis for breeding in Ukraine and forecasting their importance in the breeding process. The State Register of Breeding Entities in Animal Husbandry for 2005-2020 was used to analyze the state of pig breeding development in Ukraine. The analysis of the state of development of breeding pig breeding in Ukraine is carried out. It is shown that in the conditions of a long crisis for the last 15 years tribal pig breeding in Ukraine has undergone a significant reduction in the number of livestock, narrowing of the breed structure and change of ownership. From 2005 to 2012, the breeding pig population remained relatively stable. In 2014, part of the breeding herd remained in the uncontrolled territory of Donetsk and Luhansk regions and the Crimea, so the official statistics of tribal pigs in Ukraine for the year decreased by 72.6 thousand heads. During the period of 2014-2017, the number of breeding stock has stabilized at the level of 350340 thousand heads, but since 2018 there has been a rapid reduction. Breeding farms in the West of Ukraine in the Zakarpattya region, in the North - in the Zhytomyr and Rivne regions have ceased to exist in the last two years. In the central region of Ukraine breeding of tribal pig is most developed in Poltava region and has acounted19.8 thousand heads. Thus, as of the beginning of 2020 , 
the breeding population of pigs in Ukraine has decreased by $70 \%-77 \%$ compared to 2012-2010. Leaders in terms of the number of tribal pigs are Ternopil, Zaporizhya, Dnipropetrovsk, Poltava, Lviv regions. Currently, the breeding base of pig breeding in Ukraine consists of 72 farms, where 151,726 thousand heads of pigs of 10 breeds are bred: Large White, Duroc, Landrace, Pietren, Poltava meat, Welsh, Ukrainian meat, Ukrainian steppe white, Ukrainian steppe speckled, Red and White belted. The most numerous breeds in terms of tribal stock are the Large white and the Landrace.

Key words: pig breeding, breed, livestock, breeding boars, sows.

Дата надходження до редакції: 20.04.2021 р. 